Journal of Social Sciences (COES\&RJ-JSS)

ISSN (E): 2305-9249 ISSN (P): 2305-9494

Publisher: Centre of Excellence for Scientific \& Research Journalism, COES\&RJ LLC

Online Publication Date: $1^{\text {st }}$ October 2017

Online Issue: Volume 6, Number 4, October 2017

DOI: $10.25255 /$ jss.2017.6.4.775.786

\title{
Senator Grace Poe as Rhetor: Probing the Rhetoric of a Neophyte Filipino Presidential Candidate
}

\author{
Jerryk C. Alico \\ Instructor, MSU-Marawi Senior High School \\ Mindanao State University-Marawi, Philippines \\ Godiva E. Rivera \\ Professor, Philosophy Department \\ Chair, Graduate Studies Department \\ College of Social Sciences and Humanities \\ Mindanao State University-Marawi, Philippines
}

\begin{abstract}
:
Politics never fails to impress its contentiousness on people, especially during elections where aspirants 'court' the electorate to win. Besides monetary resources, political candidates also consider rhetoric a top machinery. Rhetoric, or the effective use of language to persuade, has been a common research interest, particularly how politicians utilize it. Unique in this study is the probe on the rhetoric of a neophyte political candidate, Senator Grace Poe, who vied for presidency during the Philippine elections in 2016. Using the framework of discourse analysis, the researcher looked into the three appeals of rhetoric - the ethos, pathos, and logos — and the different rhetorical strategies that Senator Poe used in one of her campaign speeches. Results revealed that Poe attempted to build her credibility through her father, the late actor Fernando Poe, Jr., who also ran for president but lost. As an emotional strategy, she reminisced her father's past experiences and reminded the audience about the desirable attributes of Filipinos, which clearly attempted to incite emotions to win the audience's support. Moreover, logical reasoning was also present in her rhetoric by proving claims through non-negotiable ideas and cause-effect relationship. She as well did not miss to utilize rhetorical devices such as repetition, rhetorical questions, meaningful use of we and $I$, and modality. Overall, Poe's skill to demonstrate rhetoric has not realized strong persuasiveness to influence popular votes.
\end{abstract}

Keywords:

rhetoric, discourse analysis, politics, elections, presidential candidate

\section{Citation:}

Alico, Jerryk C.; Rivera, Godiva (2017) ; Senator Grace Poe as Rhetor: Probing the Rhetoric of a Neophyte Filipino Presidential Candidate; Journal of Social Sciences (COES\&RJ-JSS), Vol.6,No.4,pp:775-786; DOI: 10.25255/jss.2017.6.4.775.786. 


\section{INTRODUCTION}

It is widely known that political candidatesare expected to persuade the people to vote for them in the elections. Since the goal is to gain as many supporters and voters as possible, candidates running for government offices should be as convincing as possible in the eyes of the majority, hence, necessitating candidates to exhaust all ways and means to win the people's support. Due to this expectation, aspiring politicians employ various techniques and strategies during their campaign endeavors, from making emotionally arousing statements in speeches to legitimize their platforms and advocacies, and even up to raising controversies against other candidates whom they want to overtake in the race.These scenarios actually characterize rhetoric or the effective use of language to persuade. Burke (1982) himself, an expert in political discourse, said that elections are a competition of rhetoric, wherepoliticians attempt to outpersuade their competitors. Borrowing Harris's (1979) words, rhetoric is a political instrument used to highlight a candidate's ideologies in a manner that is palatable to the people.

It is with no doubt that speeches delivered by political candidates have the quality of persuasiveness.As Ezejideaku and Ugwu (2007) and De Wet (2010) noted, it is the politicians' main purpose to persuade voters and political elites to support their views, thus, if successful, will bring them to power. Essentially, persuasive speeches hold unique characteristics and intentions and, according to Hakansson (1997), language is focused in elections, which could be considered the most important instrument to be victorious in the race.The language used is richly constructed and organized and the effort to deliver such speeches is expectedly vigorous. These features of persuasive speeches make such a form of discourse interesting to study, most especially when delivered during election campaigns.

In that view, the authorsagreewithBeard's (2000)idea that studying the language of politicsholds significanceas it allows us to "understand how language is used by those who wish to gain power, those who wish to exercise power and those who wish to keep power"(Beard, 2000:2).Further, Hakansson (1997) made a good point saying that political rhetoric is a powerful instrument worthy of studying. Such assertions gave impetus to the researchers to delve into the rhetoric of a Filipino presidential candidate during the Philippine national elections in 2016, the neophyte Senator Grace Poe-Llamanzares.

Some questions might arise: Why Grace Poe and why brand her a "neophyte" candidate? To outline her identity, Mary Grace Poe-Llamanzares is an adopted daughter of the prominent Philippine actors Ronald Allan Kelley Poe and Jesusa Sonora Poe, the former known as Fernando Poe Jr. who held the title "King of Philippine Cinema" and the latter known as Susan Roces. As to her experience,she was chairperson of the Philippine's Movie and Television Review and Classification Board (MTRCB) from 2010 to 2012 before entering politics. In 2013, she filed her candidacy as senator and fortunately won with the highest number of votes, despite her being a neophyte candidate with no other administrative experience except her stint in the MTRCB.Some journalists called her "first-time politician" (Elemia, 2016) and "junior senator" (Doronila, 2015), which are technically valid descriptions considering her background in politics and governance.

Hence, the main goal of this paper is to disclose Poe's rhetoric, thereby unravelling her strategies and techniques to make herself a persuasive speaker during the election campaigns.The findings of this analytical endeavor would bring to light further 
understanding on political language, particularly on the waynovice candidates use it to succeed in the contest of elections through popular voting.

\section{LITERATURE REVIEW}

\section{Rhetoric}

Rhetoric has been with humans since time immemorial, but Aristotlewas known to have commenced itssystematic study. It is commonly definedas the art and science of speaking well to persuade people. In Aduradola and Ojukwu's (2013) view, rhetorical language may be infested with lengthy and oftentimes figurative words that might lack truthfulness and earnestness.

Aristotle's classical idea of rhetoric serves as a seminal and foundational concept that is still utilized and believed to be true until today. He proposed that a speaker should consider three important elements to make a persuasive speech, namely, the speaker himself/herself, the audience, and the subject-all composing Aristotle's rhetorical triangle.In the words of Roskelly (n.d.):

Considering the subject means the writer/speaker evaluates what he or she knows already and needs to know, investigates perspectives, and determines kinds of evidence or proofs that seem most useful. Considering the audience means speculating about the reader's expectations, knowledge, and disposition with regard to the subject writers explore. The use of experience and observation brings Aristotle to the speaker point of the triangle. Writers use who they are, what they know and feel, and what they have seen and done to find their attitudes toward a subject and their understanding of a reader.

The said elements form the foundation of the three appeals used in rhetoric, which are the ethos, pathos, and logos. Ethosis an appeal in which the speaker builds her credibility through displaying knowledge and character. As Quintilian, a famous Roman rhetorician, once said, the speaker must be the "good man speaking well." Moreover, pathos is also called emotional appeal because speakers target the audience's emotions and interest. To a certain extent, this appeal is the most overused because it is the handiest and sometimes the most powerful appeal since it provokes emotions and makes it easier for the speaker to build a connection with the audience. Lastly, logosis at work when speakers provide reasonable premises and evidences for their claims.Meaning, logical thinking and reasoningare the instruments that a speaker uses to convince the audience.

\section{Studies on theRhetoric of Politicians}

A large body of research that deals with the rhetoricof politicians was reviewed and some of the remarkable ones are discussed in this section. One is the study ofAlo (2012) on the rhetorical strategies used by selected African leaders to persuade the people about the expediency and urgency of their policies, plans and actions towards African socioeconomic and political recovery of development. Major findings of his study include greetings, use of pronouns, contrasts and modality. Still using an African country, Guerra (2012) analyzed the rhetoric of Barack Obama's speech in Ghana, and found that that Obama used adjectives throughout his speech, which highlight positivity and encouragement. He also used metaphors and personal pronouns $I$ and we, modal verbs, and repetition of words for emphasis.

There are many studies on rhetoric, however, none dealt with neophyte candidates or politicians. Some studies also did not discuss further how politicians use the three appeals 
of rhetoric - the ethos, pathos, and logos. Given these reasons, the researchers consider it a research opportunity to explore political rhetoricof novice politicians, in this case, Senator Grace Poe. The findings of this exploration would forward further understanding on rhetoric as a political instrument especially on howbeginnersin political race utilize it.

\section{METHODS \\ Frame of Analysis}

This paper uses rhetorical discourse analysis (RDA) in which the focus is placed on the rhetoror the speaker as the source of discourse and on how he/she uses rhetoric to attempt to convince the audience. The analysis aims to shed light on the rhetorical devices used by a rhetor in delivering the message as well as on the three appeals used to persuade the audience: ethos (rhetor's credibility), pathos (use of emotional appeal), and logos (use of logic to prove a point).

\section{Text Analyzed}

Analyzed in this paper is the English version of the declaration speech of Senator Grace Poe-Llamanzares during her bid for the presidency. She delivered it at the University of the Philippines Bahayng Alumni, the same place where her father, Fernando Poe Jr., also announced his intention to run for the presidency in 2004. The almost 2, 000-word speech was delivered on September 16, 2015.

\section{RESULTS AND DISCUSSION}

In this section appear the results of the analysis and the discussion of findings. To reiterate, this paper aims to analyze the persuasive character of Senator Grace Poe and her linguistic appeal through rhetorical discourse analysis (RDA) of her declaration speech. The analysis of Poe's discourse generated themes and patterns, whichare discussedindividually below.

\section{Ethos Analysis: Building Credibility through Her Late Father}

In her speech, Grace Poetried to establish her credibility by reminiscing and frequently narrating the plight and experiences of her father, the late famous Filipino actor Fernando Poe, Jr. or FPJwho also ran for the same position in the 2004 elections. She mentioned the following in her speech:

"When I first asked for your help, I said that I wanted to continue what my father FPJ had started."

With this said, there was an implication that her father was not able to finish what he had put up_an aspect which Poe did notexplicitly discuss. What did her father actually start that she should continue? If she answered that she wanted to continue her father's bid for presidency, then it is not logically convincing because his father did not actually put up something relevant to governance. Although he starred in legendary action movies that reflect serious social and political issues like corruption, he was not able to hold any public office that would at least be given credit. There was no clear history of his father's experiences in leading a part of or the whole country.hence, the appeal was clearly psychological rather than rational.

She also mentioned next to the first one:

"He [FPJ] often told me: Gracia, poverty is not a destiny because each one's fate is in his/her hands. But to get out of poverty, one's own hard work is often not enough. 
Everyone needs a helping hand. Shouldn't this be the measure of a responsive government and society - how it uplifts everyone and leaves no one behind?"

In this statement she cited what FPJ told her, an attempt to tell the audience that she has been guided by her father's principles, thus she has the legitimacy to continue them by running for the presidency.

Actually, there was an attempt to use her current experience as senator, but it was quite shallow and the effect was not essentially contributory to her credibility as a public official. She said:

"Who would've thought that a foundling would ever become senator? I thank you for giving me that opportunity."

As defined, ethosputs regard tothe rhetor's image in order for him/herto build a nexus with the audience and, in turn, become a credible speaker. In the case of Senator Poe, she has never been gravely accused ofissues that would taint her as a politician like graft and corruption, incompetence, and others. However, she also did not highlight her achievements as one of the country's legislators, which could be one of the potential moves that would put up her ethos.

\section{Pathos Analysis: Appreciation, Referencing}

Public speakers, particularly political candidates, commonly inject emotional and affectively arousing remarks in order that the audience invest empathy and sympathy for the speakers. Most of the time, the emphatic political expressions of the rhetors give them an avenue to capitalize on the psychological connection built between them and the audience, which would possibly make the rhetors win the approval of the audience.

\section{Appreciation}

Grace Poe has her own way of eliciting emotions from the audience. First recurring way of evoking the listeners' emotion is her constant appreciation of the country's possessions and the Filipino qualities. To start, she mentioned:

"Don't ever forget that Filipinos are a very able race. We are loving, creative and resourceful."

"Our country is rich-in natural resources, our people's knowledge and skill, and our heroism. This is where Asia's first republic was founded. This is the country of Rizal and Bonifacio. Before women were given a voice, Gabriela Silang was already rallying an uprising. We have an amazing history from which we can draw inspiration."

It is clear that she intended to remind people of the remarkable achievements and desirable attitudes of the Filipinos as well as the historic persons of the country to create an emotive effect that the Filipinos are great people and that we should be proud and inspired. Her statement below further reinforced this.

"We have overcome many hurdles. We've been hit many times over by disaster - the strongest typhoons - that seem bent on removing us from the map. And yet, here we are, still standing."

This is emotionally suggestive, making people feel hopeful that Filipinos can overcome all challenges. She even repeated the words "We have" to utter creatively her statement and to insinuate that she and her audience are unified as one group with similar experiences. 
In her attempt to build a stronger connection with the audience so that she could gain more support, she mentioned specific individuals who, according to her, gave her an inspiration to continue with her endeavor to run for the country's highest position. She said:

"By ordinary Filipinos who are awake even before the rooster announces the morning...By those those jostling for space in the MRT or running to catch a bus or jeep to work before traffic builds up on EDSA or FuenteOsmena Boulevard in Cebu.

By those who can't get home 'til late: BPO agents working graveyard shifts, public transport drivers plying the city's roads, and fishermen out at sea.

By parents who have to be away from their children: those who endure the desert's heat, the perils of the sea, and the pain of loneliness, just to give their children a bright future. By workers with callused hands and hunched backs from working non-stop.

By ordinary government workers: teachers who traverse mountains to reach eager students; nurses who continue to give care despite their own exhaustion, policemen and soldiers who risk their lives to ensure our safety and security.

I draw inspiration from each and every one of you. You give me the strength to pursue a higher calling for our country."

The use of highly affective words clearly indicates Senator Poe's intention to establish connection with her audience. By giving worth to the struggles of every Filipino worker and by highlighting the word "ordinary" to give an impression that the grassroots citizens are her impetus to run as president manifests an emotional appeal that is essentially rhetorical. She said that probably because of the assumption that those individuals she mentioned might be present in the venue so that they would feel they are important. In addition, mentioning those struggling "ordinary" persons could probably make the "nonordinary" voters, like rich businessmen and professionals, sympathize and infer that she as a candidate has a heart for the poor and underprivileged. This has a strongrelation to her campaign tagline "Gobyernong may Puso" (Government with a heart).

Appreciation resembles what Charteris-Black (2011) callsflattery, or "appealing to the audience's goodwill or the sharing of interests between the speaker and the receivers." Thisis evident in her manner of uplifting the morale and spirit of the audience by emphasizing the good qualities of the Filipinos and by putting forth value and significance to what common Filipinos do in their daily lives.

\section{Family Referencing}

To create further emotional response from the audience, Poe also referenced her family in supporting her ideas. These include her father and mother, whom she implies as influential individuals to her. Focusing on her father, shesaid:

To our Moro brothers, your culture and heroism were the inspiration for many of my father's films. After a long and hard history, it is time that you are given equal opportunities and genuine assistance.

When my father ran for the presidency, he was ridiculed; his inexperience was scoffed at and his citizenship questioned. Yet he bravely faced the challenge and the opportunity to 
help change the lives of his fellow Filipinos for the better. His integrity, courage and goodness have become both my guide and inspiration.

On the other hand, she alsoreferenced her mother by saying:

My mother also gave me sound advice. She said, "My child, amidst the loud noise of politics, never ever lose yourself."

It is evident in the lines above that her family, particularly her parents, is highlighted as significant personalities in her endeavors especially in running for the presidency. She even put emphasis on their positive values and qualities to present an image of their being good influences to her, thus, implying that she was raised well, possessing their admirable traits.In relation to this, Charteris-Black (2011) noted that in appealing to the audience's pathos, rhetorsplace emphasis on personal experiences and on their family especially if they have established fame.This idea clarifies the latent intention of Senator Poe in recalling her encounters with her family, especially her prominent adoptive parents.

\section{Empathy}

Lastly, it also emerged in Poe's speech her attempt to make the audience feel that she is one with them, particularly on their aspirations, hopes, challenges and daily struggles. The promise to be with every ordinary Filipino in searching for good life and in attaining a peaceful nation when her presidency comes is empathy. Politicians making promises is a classical pathosused to enforce effective persuasion strategy.

Furthermore, she used her being a mother as basis specifically on the issue of crime and drugs, to quote:

As a mother, I am deeply troubled by the proliferation of crime and drugs. Like every parent, I cannot rest easy until my children are home safe at night.

Apparently, she attempted to connect with the audience, perhaps the mothers and the youth, by presenting her concern for the children's safety and security, which is an emotionally driven idea as well.Furthermore, the concluding statement in her speech also showed her attempt to empathize, that is:

I am Grace Poe. A Filipino. A daughter, wife and mother.

In that statement, she mentioned her different identities, whichsignals audience to imagineher different roles and responsibilities as well, hence, implying that her multifaceted personality allows her to understand and empathize with different individuals in the society.

\section{Logos Analysis: Non-negotiable Aspects, Cause-Effect Supporting a Claim using Non-negotiable Values}

The use of logical explanations also emerged in Grace Poe's speech, specifically on the part where she was discussing her platforms for the country, although minimal only. Some of her statements are the following:

People know what their needs are and they have a right to choose how to spend their hard-earned money. But if government lowers taxes, we should reciprocate by paying the right taxes. 
Every worker needs a decent and legal source of income.

We will pursue peace with all groups.

We should respect human rights.

Everyone's health is important.

In the above statements, she tried to prove the importance of her platforms to the country by pointing out non-negotiable aspects and values at the start of her statements such as the right to choose, peace, source of income, human rights, and health. In essence, these values, if used as premises of the argument that people should vote for her probably sounds acceptable and cogent for there are concrete governance principles that are propeople, pro-economy, pro-peace, and above all, pro-human rights.In particular, economic and health programs are basic needs of the people, which, obviously, the government should provide.

\section{Proving a Point through Cause-and-Effect}

Another technique used by Poe in her speech to support her propositions is by pointing out the possible, desirable, and concrete outcomes of her programs in behalf of the country. Some of her statements appear below:

"As more products "Made in the Philippines" flourish, more jobs will be created."

"With peace, real progress can touch all corners of the country."

"Many jobs will become more productive with faster internet connection. Kids will finish their homework faster and we can more easily talk to our loved ones working overseas without any Skype delays."

The above statements show that Senator Poe wanted to impress on the people that her platforms (the cause) will directly result in the achievement of the desired ends (e.g. jobs, progress). Thisfurther suggests that Grace Poe wanted to give people an assurance that her programs would be the better way to accomplish the objectives of the government.However, thismanner of explainingallows doubts about her logic to come forward. On one hand, it is theoretically true that the cause (e.g. peace) would lead to the attainment of the effect (e.g. real progress).On the other hand, what this explanation lacks is the process that happens between the cause and the effect. There should be a clear elaboration on how she will proceed from point A to point B. Hence, there is a need for her to further her argument by operationalizing the direct relationship between the cause and the effect. Since this was absent, Grace Poe's logosneeds to be strengthened.

\section{Rhetorical Strategies}

Senator Poe also utilized some rhetorical devices to make her speech sound persuasive in the ears of the audience.

\section{Rhetorical Questions}

In Poe's speech appears some rhetorical questions that emphasize her ideas and show her creativity. These statement include:

How can one be not amazed by the daily triumph over struggles of our countrymen? Who would've thought that a foundling would ever become senator?

Poe's questions above actually resemble rhetorical questions that need not to be answered anymore because the answers are already expected and assumed to be favorableto her. Hence, these questions' function is to highlight further that as to the people's questions 
regarding the future of the nation, Senator Grace Poe, a presidential candidate, is the answer.

\section{Repetition of Words, Phrases and Grammatical Structures}

Another evident strategy employed by Poe to reinforce her rhetoric is repeating some words, phrases, and grammatical structures.First is her repetition of the preposition by in enumerating the different individuals that brought her inspiration. To mention some:

...By the daily triumph over struggles of our countrymen

By ordinary Filipinos who are awake...

By thosethose jostling for space in the MRT...

By those who can't get home 'til late...

By parents who have to be away from their children...

By workers with callused hands and hunched backs...

By ordinary government workers...

Other repetitive words and phrases in Poe's speech also pertain to the following examples, which she used to start her sentences:

Any progress we achieve...

Any preferential bias...

Aside from repetitions of words/phrases, Poe also demonstrated a unique way of starting a paragraph, particularly when she discussed her platforms, and that is by starting it with a description of the platform's main subject, which is then followed by her stand on that issue and her plan to achieve it. Some examples are the following:

We have one of the highest tax rates in the world. My aim is to lower these.

A large percentage of a family's earnings goes to paying for electricity. We need to find a way to lower power costs.

Everyone's health is important. I will ensure that each community has a proper hospital... The West Philippine Sea is ours. We will protect our right through peaceful means, and according to international law.

The traffic situation takes away not just our precious time, it tests our patience. We should do the following: We should build more roads and trains...

Children are the nation's treasure. They are our present and future... It is time to create a Standard Lunch Program in all public schools.

This technique seems friendly to the listeners because it is easy to follow, and since it is used repeatedly in the speech, it is subconsciously implanted into the listeners' minds, which could make the speech clear and understandable.In support for this, Cirugeda and Ruiz (2013) claim that if words and ideasare repeated, theyareeasily recorded in the consciousness of the audience, making the speech remarkable and persuasive.

\section{Use of Pronouns "We" and " $I$ "}

Common among politicians is the use of the personal pronouns we and $I$ in certain instances in their speech. In the case of Senator Poe, she used wewhendiscussing issues and concerns that need the cooperation of the whole citizenry or when pointing out positive things about the country and the Filipinos. Some of them are the following:

In education, we must attend to the needs of our classrooms. We shall strive to expand our scholarship programs and strengthen the "Study now, pay later" program.

We shall work for the flourishing of the agricultural sector.

We need to find a way to lower power costs.

We will pursue peace with all groups. 
We should respect human rights.

We will rise and progress together as one nation.

We are loving, creative and resourceful.

Mentioned above are just a few of Poe's statements with the pronoun we. In fact, the pronoun was used 66 times in her speech, whichsuggests Poe intended to send a message that her political aspirations are for the people and always involve the people. Her use of wealso implies that her whole political party, which include her running mate Senator FrancisEscudero as Vice President and their line-up of senators and party members, will fulfil their platforms. Thus, the electorate should vote them altogether during the final voting day.

Besides the plural personal pronoun we, Poe also made use of the first person personal pronoun $I$, which suggests that she tried to emphasize her own self and her personal stand on certain issues to make herself noteworthy to the audience. Here are some examples:

I draw inspiration from each and every one of you.

I would like to make known to everyone that it I've made it my dream and my purpose to attain, with your help, the following...

I will strive to increase the annual infrastructure budget to $7 \%$ of the GDP.

I will push for the passage of the Freedom of Information bill at the soonest possible time. And this I guarantee: Every peso you pay will be returned to you in fast and quality service.

For me, the elimination of drugs and crime is not just a job. It is my personal crusade. I will make sure the police have the required discipline and skills to immediately deal with crime.

I will ensure that each community has a proper hospital...

In this case, Poe focused on herself as the doer of the actions and plans, which suggests that if she finally holds the power, her plans would successfully materialize.In doing so, she sends a message to the audience that she is responsible for those matters and she will initiate the move to fulfil them.

\section{Modality: will, should}

Last on the list of rhetorical strategies that Poe employed was her constant use of modal verbs will, should and can. Accordingly, modal verbs function not only as auxiliary words but also as meaningful lexicons that help reflect the speakers' ideas and intentions.Found in her speech are the following:

Should:

We should push for true reforms that will achieve inclusive growth, global competitiveness and transparent government.

We should maximize digital technology for education, and eliminate backlogs.

Filipinos should need no longer kill fellow Filipinos.

We should respect human rights.

Poe's use of should implies that the subject or issue she mentioned are of great importance and that her administration must do them and make them happen on the ground.

Will:

We will also help college students find internships and jobs to gain invaluable experience even before they graduate.

We will push for mechanization.

We will make infrastructure development our priority... 
We will hold the corrupt accountable, whether they be friend or foe.

We will value our OFWs and take care of them.

We will pursue peace with all groups.

Semantically speaking, the modal willis used to state a fact or action that will happen or be done in the future with certainty. In other words, it is used to state a promise that a speaker will surely fulfil. In this view, Poe seems to impress on the people that she is committed to make her platforms a reality.

\section{CONCLUSION}

What transpired in the analysis of Senator Grace Poe's declaration speech is the implication that rhetoric holds great importance as a political machinery in any political race. Since elections are also a competition of persuasive skills, politicians might as well must utilize it exhaustively to their advantage.Grace Poe's speech still resembles the Greek's classic structure of persuasive speech that uses the three types of appeal, the ethos, pathos, and logos, to create a desirable personality that would eventually convince the audience. However, her speech gave more emphasis onethosandpathos, while there was not much effort to build realistically and logically her logos.In a context where the audience is not only composed of credulous, gullible individuals who only follow their emotions to vote, political candidates should include sound argumentation supported by credible sources and evidences. Needed as well are concrete and realistic platforms, backed by extensive knowledge and experience on implementing such platforms in the real world. Poe, in the first place, lacks experience in terms of policymaking and governance, given the fact that she only held several positions in short spans of time. To put simply, Grace Poe as a rhetor still needs to build her credibility and improve her use of logical reasoning.Moreover, her brand of rhetoric might have suffered from its being common and predictable, especially that there were other contesting brands of rhetoric during the race, like that of President Rodrigo Duterte, which displayed fierce and hardline stance on issues.

Finally, aspiring candidates who attempt to persuade the people should strike a balance among the three appeals. Because psychological invocation alone cannot suffice, effective persuasion is apparently achieved when personal and rational appeals are well-tailored in a speech. In addition, political candidates, especially neophytes, should strategize a novel brand of rhetoric that would stand outin the contest of leadership.

\section{REFERENCES}

Aduradola, R. \&Ojukwu, C. (2013). Language of Political Campaigns and Politics in $\begin{array}{lllll}\text { Nigeria. } \quad \text { Canadian Social Science, } 9 & \text { (3), }\end{array}$ doi:10.3968/j.css.1923669720130903.9650.

Alo, M. (2012). A Rhetorical Analysis of Selected Political Speeches of Prominent African Leaders.British Journal of Arts and Social Sciences, 10 (1), 87-100.

Beard, A. (2000). The Language of Politics. London: Routledge.

Brody, J. E. (2007, December 11). Mental reserves keep brain agile. The New York Times. Retrieved from http://www.nytimes.com

Burke, R. (1982O. Politics as Rhetoric. Ethics, 93 (1), 44-55.

Charteris-Black, J. (2011). Politicians and Rhetoric. Second edition. The Persuasive Power of Metaphor. Hampshire/New York: Palgrave Macmillan. 
Cirugeda, I. \& Ruiz, R. (2013). Persuasive Rhetoric in Barack Obama's Immigration Speech: Pre- and Post-Electoral Strategies. Camino Real, 5 (8), 81-99.

De Wet, J.C. (2010). The Art of Persuasive Communication - A Process. Claremont: Juta\& Company Ltd.

Doronila, A. (2015, October 2). Grace Poe's Messianic Pretensions. Philippine Daily Inquirer. Retrieved from http://opinion.inquirer.net/89046/grace-poes-messianicpretensions\#ixzz4Zg1zLFln

1.1.1.1.1.1 Elemia, C. (2016, May 21). Grace Poe and the lost presidency. Rappler. Retrieved from http://www.rappler.com/nation/politics/elections/2016/133522-gracepoe-what-went-wrong-campaign

Ezejideaku, E. and Ugwu, E. (2007). The Rhetoric \& Propaganda of Political Campaigns in Nigeria", JOLAN, 10, 9-26.

Guerra, C. (2012). Outstanding Rhetorical Devices and Textuality in Obama's Speech in Ghana, Africa. Open Journal of Modern Linguistics, 2 (3), 97-104. http://dx.doi.org/10.4236/ojml.2012.23013

Hakansson, N. (1997). Election Rhetoric of Political Parties: An Appraisal and A Proposal. The Public, 4 (3), 81-95.

Harris, P. (1979). Foundations of science. London: Hutchinson and Co. Publishers.

Rappler. Full Text: 'I wanted to continue what FPJ had started' - Grace Poe. Retrieved from http://www.rappler.com/nation/politics/elections/2016/106112-full-text-grace-poedeclaration-president-english.

Roskelly, H. (2008). What do students need to know about rhetoric? Special Focus in English Language and Composition: Rhetoric. Retrieved from http://apcentral.collegeboard.com/apc/members/repository/ap06_englang_roskelly_50098. pdf 